\title{
Mineral requirements for growth of wool and hair lambs ${ }^{1}$
}

\author{
Izabelle Auxiliadora Molina de Almeida Teixeira², Kléber Tomás de Resende ${ }^{2}$, Aderbal Marcos \\ de Azevêdo Silva ${ }^{3}$, Américo Garcia da Silva Sobrinho², Carla Joice Härter², Ana Paula de \\ Oliveira Sader ${ }^{2}$
}

\footnotetext{
${ }^{1}$ Financially supported by Fundação de Amparo à Pesquisa do Estado de São Paulo (FAPESP proc. 98/06746-2).

${ }^{2}$ Department of Animal Sciences, Universidade Estadual Paulista/UNESP, Jaboticabal, SP, Brazil, 14884-900.

${ }^{3}$ CSTR, Universidade Federal de Campina Grande, Patos, PB, Brazil, 58700-970.
}

\begin{abstract}
The present study was conducted to determine the body composition and the mineral requirements for growth of wool and hair lambs. A total of 34 castrated lambs with an initial body weight (BW) of $19.9 \pm 0.8 \mathrm{~kg}$ were used; 17 of these lambs were of the genotype Ideal $\times$ Ile de France and 17 were Santa Inês. Ten lambs (5 of each genotype) were slaughtered at the beginning of the experiment to establish their initial body composition. The remaining lambs were assigned to one of three diets ( $40 \%$ roughage and $60 \%$ concentrate, $60 \%$ roughage and $40 \%$ concentrate, or $80 \%$ roughage and $20 \%$ concentrate) in a $2 \times 3$ factorial arrangement of treatments. All of the diets were provided ad libitum. When the group under $40 \%$ roughage and $60 \%$ concentrate reached $35 \mathrm{~kg} \mathrm{BW}$, all of the animals were slaughtered. Linear regressions were used to determine the relationship between the shrunk BW and the empty body weight (EBW) for each genotype. These equations were compared and revealed differences between the genotypes. The allometric equations were calculated using the relationship between the amount of minerals and the EBW. The equations of a given mineral for each genotype were compared to verify if they were statistically different. The equations for calcium, phosphorus, magnesium and sodium differed between genotypes. The same equations were used to estimate the major body mineral composition per kilogram of EBW. The net requirement for gain of the fleece-free Ideal $\times$ Ile de France lambs ranged from 7.77 to $6.80 \mathrm{~g} \mathrm{Ca}, 4.54$ to $4.14 \mathrm{~g} \mathrm{P}, 0.30$ to $0.27 \mathrm{~g} \mathrm{Mg}, 1.18$ to $1.07 \mathrm{~g} \mathrm{~K}$ and 0.84 to $0.76 \mathrm{~g} \mathrm{Na}$ per $\mathrm{kg} \mathrm{BW}$ gain, and the requirements of the Santa Inês animals ranged from 9.57 to $8.37 \mathrm{~g} \mathrm{Ca}$, 5.39 to $4.91 \mathrm{~g} \mathrm{P}, 0.36$ to $0.33 \mathrm{~g} \mathrm{Mg}, 1.18$ to $1.07 \mathrm{~g} \mathrm{~K}$ and 0.90 to $0.81 \mathrm{~g}$ Na per $\mathrm{kg} \mathrm{BW}$ gain for the lambs weighting 20 to $35 \mathrm{~kg}$. Santa Inês lambs showed higher requirements for $\mathrm{Ca}, \mathrm{P}, \mathrm{Mg}$ and $\mathrm{Na}$.
\end{abstract}

Key Words: body composition, major mineral, net requirements, sheep

\section{Introduction}

Minerals are important elements that are required in small amounts by all animals. These minerals perform essential functions in the body and are directly involved in their productive performance (NRC, 2007).

Factors such as gender, genotype, age and the physiological state of the animals influence their mineral requirements. Animals of different genotypes are well known to exhibit differences in their requirements due to the differences in their body composition. These differences result from the influence of a favorable environment on the phenotypic expression of a given genotype (Sober, 1984; Oddy \& Sainz, 2002; Wiseman et al., 2009; Wiseman \& Mahan, 2010).

Such differences between genotypes have only rarely been considered in studies on the nutritional requirements of sheep, and studies of mineral requirements for these genotypes are rare. Consequently, feeding systems for sheep include the recommended mineral requirements that are independent of the genotype of an animal (ARC, 1980; NRC, 2007; CSIRO, 2007). Therefore, the actual and expected performance that results from these systems may differ. Accordingly, it is necessary to establish mineral requirements for different sheep genotypes to obtain a more efficient and economic production system. In addition, the AFRC (1991) and NRC (2007) have recommended that new studies on the nutrient requirements of different breeds be undertaken in different environments because of the influence of breed and environment on the requirements of the animals. This study was therefore conducted to determine the body mineral composition and the net requirements for gain of two sheep genotypes: Santa Inês and Ideal $\times$ Ile de France lambs.

\section{Material and Methods}

The experimental procedures of this study were approved by the Ethics Commmittee of Universidade Estadual Paulista, UNESP, campus Jaboticabal. The study was carried out at 
the sheep facility of UNESP, campus Jaboticabal, Brazil ( $21^{\circ} 15^{\prime} 22^{\prime \prime} \mathrm{S}$ and $48^{\circ} 18^{\prime} 58^{\prime \prime} \mathrm{W}, 595 \mathrm{~m}$ altitude). The experiment began in July and ended in December. During this time period, the average temperature and relative humidity were $22.5^{\circ} \mathrm{C}$ and $69.7 \%$, respectively.

Seventeen Ideal $\times$ Ile de France and 17 Santa Inês castrated male lambs with an initial average BW of $19.9 \pm 0.82 \mathrm{~kg}$ were used for the present study. Ten lambs (five of each genotype) were slaughtered at the beginning of the experiment to establish their initial body composition (baseline animals). The remaining lambs were allocated to three groups of eight (four from each genotype) and were assigned to one of three diets (40\% roughage and $60 \%$ concentrate, $60 \%$ roughage and $40 \%$ concentrate, or $80 \%$ roughage and $20 \%$ concentrate) in a $2 \times 3$ factorial arrangement of treatments. When the animals in the $40 \%$ roughage and $60 \%$ concentrate treatment group reached $35 \mathrm{~kg} \mathrm{BW}$, all of the animals were slaughtered. On average, the lambs in the $40 \%$ roughage and $60 \%$ concentrate, $60 \%$ roughage and $40 \%$ concentrate, and $80 \%$ roughage and $20 \%$ concentrate diets weighed $35.23 \pm 1.49,31.01 \pm 1.31$ and $26.01 \pm 1.68 \mathrm{~kg}$ BW when slaughtered, respectively. The lambs were housed individually indoors in pens that measured $1.0 \mathrm{~m}^{2}$, equipped with a feed trough and an automatic water supply.

The $40 \%$ roughage and $60 \%$ concentrate ration was formulated to meet the requirements for crude protein (CP), metabolizable energy (ME) and minerals, according to ARC (1980) and AFRC (1992), to result in a growth rate of $300 \mathrm{~g} / \mathrm{d}$. The experimental diets (Table 1) contained Tifton 85 hay (Cynodon dactylon) in the late vegetative stage and a concentrate that contained soybean meal, corn grain, limestone, $\mathrm{NaCl}$ and a mineral premix. The different amounts of roughage were used to produce a decrease in the nutrient intake and different average daily gain (ADG). The diets were provided ad libitum twice a day: at $07 \mathrm{~h} 00$ and at $16 \mathrm{~h} 00$.
Before slaughter, the Ideal $\times$ Ile France lambs were shorn, and the wool was weighed. Prior to slaughter, lambs did not have access to food for 24 hours and were deprived of water for 12 hours. Immediately before slaughter, lambs were weighed, and shrunk body weight (SBW) was recorded. After, they were stunned by cutting their carotids and jugular. The blood was collected, and the gastrointestinal tract was removed and weighed before and after its contents were removed. The weights of the gastrointestinal tract, bladder and gallbladder contents were used to determine the empty body weight (EBW). The whole body, including the blood, organs, head, feet, and carcass, was ground, homogenized and a sample was collected and frozen.

The frozen empty body samples were individually homogenized, and a representative subsample of $100 \mathrm{~g}$ was freeze-dried for 72 hours to determine the dry matter (DM) content of each sample. The freeze-dried samples were defatted in a Soxhlet apparatus and ground in a ball mill. The resulting materials were used to determine the mineral content of the samples (method number 924.05; AOAC, 1990).

To calculate the body composition, the amount of a mineral in the empty body (g) was regressed on the EBW, using the logarithmized allometric equation (Eq. [1]; ARC, 1980).

$$
\log _{10} y=a+b \log _{10} E B W
$$

where $y$ is the amount of a mineral in the empty body (g); EBW is given in $\mathrm{kg}$; $\mathrm{a}$ is the intercept; and $\mathrm{b}$ is the slope of equation.

Equation 1 was differentiated to compute the estimates of the composition of gain at various EBW (Eq. [2]).

$$
y^{\prime}=b 10^{\mathrm{a}} \mathrm{EBW}^{(\mathrm{b}-1)} \text {, }
$$

where $y^{\prime}$ is the mineral per unit of the empty weight gain (in $\mathrm{g} / \mathrm{kg}$ of gain); EBW is given in $\mathrm{kg}$; and $\mathrm{a}$ and $\mathrm{b}$ are the coefficients from a linear regression (Eq. [1]).

To estimate the net mineral requirements for $\mathrm{BW}$ gain, the values of composition of gain were divided by the BWto-EBW ratio factor that was calculated for each genotype.

\begin{tabular}{|c|c|c|c|c|c|c|c|c|}
\hline Ingredient & $\begin{array}{l}\text { Dry matter } \\
\text { (as fed) }\end{array}$ & $\begin{array}{l}\text { Crude protein } \\
\text { (\% of DM) }\end{array}$ & $\begin{array}{c}\text { Metabolizable } \\
\text { energy (kcal/kg) }\end{array}$ & $\begin{array}{c}\mathrm{Ca} \\
\text { (\% of DM) }\end{array}$ & $\begin{array}{c}\mathrm{P} \\
(\% \text { of DM) }\end{array}$ & $\begin{array}{c}\mathrm{Mg} \\
\text { (\% of DM) }\end{array}$ & $\begin{array}{c}\mathrm{K} \\
(\% \text { of DM) }\end{array}$ & $\begin{array}{c}\mathrm{Na} \\
(\% \text { of DM) }\end{array}$ \\
\hline Tifton 85 hay & 91.7 & 7.3 & 1800 & 0.74 & 0.13 & 0.22 & 1.72 & \\
\hline Corn grain & 87.0 & 8.8 & 2780 & 0.003 & 0.24 & 0.11 & 0.32 & \\
\hline Limestone & 99.9 & - & - & 38.2 & 0.003 & 0.20 & 0.007 & 0.012 \\
\hline Mineral premix & 94.1 & - & - & 18.4 & 6.2 & 5.3 & 0.11 & 5.2 \\
\hline $\mathrm{NaCl}$ & 98.0 & - & - & & & & & 39.8 \\
\hline $60 \% \mathrm{R} 40 \% \mathrm{C}$ & 90.1 & 11.7 & 2173 & 0.64 & 0.23 & 0.220 & 1.36 & 0.17 \\
\hline $80 \%$ R $20 \% \mathrm{C}$ & 90.9 & 9.5 & 1987 & 0.69 & 0.18 & 0.222 & 1.54 & 0.09 \\
\hline
\end{tabular}

Table 1 - Chemical composition of the ingredients and the diets, on a dry matter basis 
In the Ideal $\times$ Ile de France lambs, the authors studied the fleece-free body composition because they adopted the factorial method to estimate the net requirements. Therefore, the mineral composition of the wool should be considered separately to estimate the requirements for wool growth.

The experimental design was a completely randomized design in a $3 \times 2$ factorial treatment structure that included the factors diet (3) and genotype (2). The statistical analyses were performed using software SAS (Statistical Analysis System, version 9.2). The linear regression analyses were performed using PROC MIXED.

\section{Results}

Linear regressions were used to determine the relationship between the shrunk BW and the empty body weight for each genotype. These equations were compared and revealed differences $(\mathrm{P}<0.01)$ between the genotypes (Table 2).

The allometric equations were calculated using the relationship between the amount of major minerals and the empty body weight. The equations of a given mineral for each genotype were compared to verify if they were statistically different. The equations for calcium, phosphorus, magnesium and sodium differed between genotypes $(\mathrm{P}<0.01)$, (Table 2$)$. However, the equations for potassium did not differ between genotypes $(\mathrm{P}>0.05)$. Therefore, a general equation is presented for this mineral (Table 2). The same equations were used to estimate the major body mineral composition per kilogram of empty body weight (Table 3 ).

In both genotypes, the proportion of minerals in the empty body decreased as the EBW increased (Table 3).
The body composition values for calcium, phosphorus, magnesium and sodium were higher in the Santa Inês lambs $(\mathrm{P}<0.01)$. The mineral body compositions of these lambs decreased from 15.38 to $12.43 \mathrm{~g} \mathrm{Ca} / \mathrm{kg} \mathrm{EBW}$, from 7.36 to $6.34 \mathrm{~g} \mathrm{P} / \mathrm{kg} \mathrm{EBW}$, form 0.47 to $0.42 \mathrm{~g} \mathrm{Mg} / \mathrm{kg} \mathrm{EBW}$ and from 1.28 to $1.09 \mathrm{~g} \mathrm{Na} / \mathrm{kg} \mathrm{EBW}$, for lambs weighting from 20 to $35 \mathrm{~kg}$. The same equation described the potassium concentrations for both genotypes. In other words, the potassium body composition values of both genotypes were similar.

The equations presented in Table 2 were differentiated to obtain the equations for estimating the composition of the gain (Table 4). The amount of the mineral showed a negative linear relationship with the empty weight gain.

The estimated concentrations of $\mathrm{Ca}, \mathrm{P}, \mathrm{Mg}$ and $\mathrm{Na}$ in the empty weight gain were higher in the Santa Inês lambs. The amount of potassium in both genotypes was estimated to vary from 1.18 to $1.07 \mathrm{~g} / \mathrm{kg}$ for the empty weight gain when the BW ranged from 20 to $35 \mathrm{~kg}$.

To estimate the net mineral requirement for BW gain, the values of composition of gain were divided by the SBW-to-EBW ratio, which were 1.18 and 1.13 for the Santa Inês and Ideal $\times$ Ile de France lambs, respectively.

The Santa Inês lambs required more $\mathrm{Ca}, \mathrm{P}, \mathrm{Mg}$ and $\mathrm{Na}$ than the fleece-free Ideal $\times$ Ile de France lambs. The opposite trend was observed for $\mathrm{K}$. These findings reflect the results for the body composition analysis (Table 5).

\section{Discussion}

The ARC (1980) considers the mineral concentration in the body to remain constant and to be independent of increases in body weight, in sheep. Under this feeding

Table 2 - Regression equations for empty body weight (EBW) on shrunk body weight (SBW) and the amount of calcium, phosphorus magnesium, potassium and sodium in the empty body weight of Santa Inês and fleece-free Ideal $\times$ Ile de France lambs

\begin{tabular}{|c|c|c|c|}
\hline Parameter & Equation & Root mean square error & $\mathrm{P}$ \\
\hline \multicolumn{4}{|c|}{ Fleece-free Ideal $\times$ Ile de France } \\
\hline EBW, kg & $\mathrm{EBW}=-2.32 \pm 0.05+0.969 \pm 0.02 \mathrm{SBW}$ & 0.602 & $<0.01$ \\
\hline $\mathrm{Ca}, \mathrm{g}$ & $\log \mathrm{Ca}=1.496 \pm 0.10+0.669 \pm 0.07 \log \mathrm{EBW}$ & 0.045 & $<0.01$ \\
\hline $\mathrm{P}, \mathrm{g}$ & $\log \mathrm{P}=1.070 \pm 0.08+0.77 \pm 0.06 \log \mathrm{EBW}$ & 0.036 & $<0.01$ \\
\hline $\mathrm{Mg}, \mathrm{g}$ & $\log \mathrm{Mg}=-0.1692 \pm 0.08+0.80 \pm 0.06 \log \mathrm{EBW}$ & 0.04 & $<0.01$ \\
\hline $\mathrm{K}, \mathrm{g}$ & $\log \mathrm{K}=0.502 \pm 0.08+0.761 \pm 0.06 \log \mathrm{EBW}$ & 0.036 & $<0.01$ \\
\hline $\mathrm{Na}, \mathrm{g}$ & $\log \mathrm{Na}=0.388 \pm 0.05+0.744 \pm 0.04 \log \mathrm{EBW}$ & 0.024 & $<0.01$ \\
\hline \multicolumn{4}{|l|}{ Santa Inês } \\
\hline EBW, kg & $\mathrm{EBW}=-3.29 \pm 0.05+0.969 \pm 0.02 \mathrm{SBW}$ & 0.602 & $<0.01$ \\
\hline $\mathrm{Ca}, \mathrm{g}$ & $\log \mathrm{Ca}=1.586 \pm 0.10+0.669 \pm 0.07 \log \mathrm{EBW}$ & 0.045 & $<0.01$ \\
\hline $\mathrm{P}, \mathrm{g}$ & $\log \mathrm{P}=1.144 \pm 0.08+0.77 \pm 0.06 \log \mathrm{EBW}$ & 0.036 & $<0.01$ \\
\hline $\mathrm{Mg}, \mathrm{g}$ & $\log \mathrm{Mg}=-0.084 \pm 0.09+0.80 \pm 0.06 \log \mathrm{EBW}$ & 0.04 & $<0.01$ \\
\hline $\mathrm{K}, \mathrm{g}$ & $\log \mathrm{K}=0.502 \pm 0.08+0.761 \pm 0.06 \log \mathrm{EBW}$ & 0.036 & $<0.01$ \\
\hline $\mathrm{Na}, \mathrm{g}$ & $\log \mathrm{Na}=0.417 \pm 0.05+0.744 \pm 0.04 \log \mathrm{EBW}$ & 0.024 & $<0.01$ \\
\hline
\end{tabular}


Table 3 - Calcium, phosphorus, magnesium, potassium and sodium content (g/kg EBW) in the empty body of Santa Inês and fleece-free Ideal $\times$ Ile de France lambs, with body weights from 20 to $35 \mathrm{~kg}$

\begin{tabular}{|c|c|c|c|c|}
\hline & \multicolumn{4}{|c|}{ Body weight $(\mathrm{kg})$} \\
\hline & 20 & 25 & 30 & 35 \\
\hline \multicolumn{5}{|c|}{ Fleece-free Ideal $\times$ Ile de France } \\
\hline Empty body weight, $\mathrm{kg}$ & 17.02 & 21.86 & 26.69 & 31.53 \\
\hline Calcium & 12.26 & 11.29 & 10.57 & 10.00 \\
\hline Phosphorus & 6.12 & 5.78 & 5.52 & 5.31 \\
\hline Magnesium & 0.38 & 0.37 & 0.35 & 0.34 \\
\hline Potassium & 1.61 & 1.52 & 1.45 & 1.39 \\
\hline Empty body weight, $\mathrm{kg}$ & 16.05 & 20.89 & 25.72 & 30.56 \\
\hline Calcium & 15.38 & 14.10 & 13.16 & 12.43 \\
\hline Phosphorus & 7.36 & 6.93 & 6.60 & 6.34 \\
\hline Magnesium & 0.47 & 0.45 & 0.43 & 0.42 \\
\hline Potassium & 1.64 & 1.54 & 1.46 & 1.40 \\
\hline Sodium & 1.28 & 1.20 & 1.14 & 1.09 \\
\hline
\end{tabular}

Table 4 - Calcium, phosphorus, magnesium, potassium and sodium concentrations ( $\mathrm{g} / \mathrm{kg}$ gain) in empty weight gain of Santa Inês and fleecefree Ideal $\times$ Ile de France lambs, with body weights from 20 to $35 \mathrm{~kg}^{1}$

\begin{tabular}{|c|c|c|c|c|}
\hline Empty body weight $(\mathrm{kg})$ & 20 & 25 & 30 & Equation \\
\hline \multicolumn{5}{|c|}{ Fleece-free Ideal $\times$ Ile de France } \\
\hline Calcium & 7.77 & 7.22 & 6.80 & $\mathrm{Ca}=20.96 \mathrm{EBW}^{-0.331}$ \\
\hline Phosphorus & 4.54 & 4.31 & 4.14 & $\mathrm{P}=9.46 \mathrm{EBW}^{-0.230}$ \\
\hline Potassium & 1.18 & 1.12 & 1.07 & $\mathrm{~K}=2.42 \mathrm{EBW}^{-0.239}$ \\
\hline Sodium & 0.84 & 0.80 & 0.76 & $\mathrm{Na}=1.82 \mathrm{EBW}^{-0.256}$ \\
\hline \multicolumn{5}{|l|}{ Santa Inês } \\
\hline Magnesium & 0.36 & 0.35 & 0.33 & $\mathrm{Mg}=0.66 \mathrm{EBW}^{-0.200}$ \\
\hline Potassium & 1.18 & 1.12 & 1.07 & $\mathrm{~K}=2.47 \mathrm{EBW}^{-0.239}$ \\
\hline Sodium & 0.90 & 0.85 & 0.81 & $\mathrm{Na}=1.94 \mathrm{EBW}^{-0.256}$ \\
\hline
\end{tabular}

${ }^{1}$ Calculated by equations derived from the weight of the minerals in the empty body.

system, the estimated mineral concentrations in the empty body are $11.0 \mathrm{~g}$ of $\mathrm{Ca}, 6.0 \mathrm{~g}$ of $\mathrm{P}, 0.41 \mathrm{~g}$ of $\mathrm{Mg}, 1.80 \mathrm{~g}$ of $\mathrm{K}$ and $1.10 \mathrm{~g}$ of $\mathrm{Na} / \mathrm{kg} \mathrm{EBW}$. The average values that were found in this study for the fleece-free wool animals of 20 to $35 \mathrm{~kg} \mathrm{BW}$ were similar to the values that are recommended by the ARC (1980). However, our study revealed differences in the concentration of these minerals with increases in BW. This result agrees with the findings from previous studies (Kellaway, 1973; Thompson et al., 1988; Geraseev et al., 2001; Wiseman et al., 2009). For the mineral proportions in the body to remain constant, it would be necessary for the muscle, bone and fat deposition to increase at the same rate and in the same proportion; however, this is not the case (Berg \& Butterfield, 1976; Sainz, 2000; Lawrence \& Fowler, 2002). Comparing these results with those given by the ARC (1980), the amounts of $\mathrm{Ca}$ and $\mathrm{P}$ that observed in the Ideal $\times$ Ile de France lambs herein were 23 and $31 \%$ lower for $\mathrm{Ca}$, respectively, and 17 and $24 \%$ lower for $\mathrm{P}$, respectively, when the $\mathrm{BW}$ ranged from 20 to $35 \mathrm{~kg} \mathrm{BW}$. The $\mathrm{Mg}$ and $\mathrm{K}$ concentrations in the empty weight gain that were observed in this study were lower than the recommendations of the ARC (1980).

The decrease in the proportion of minerals as the BW increases can be explained by the increase in the fat deposition in the body of animals. This increase in fat deposition results in the dilution of minerals in the composition of the body with increases in BW (Nour \& Thonney, 1987). Protein requirements for growth have also been determined in this study (Silva et al., 2007). The body composition data on protein and fat were used to calculate the mineral concentrations in the degreased body (grams $/ \mathrm{kg}$ fat-free empty body). The results indicated a constant mineral proportion that was independent of variations in body weight, from 20 to $35 \mathrm{~kg} \mathrm{BW}$. These findings confirmed 


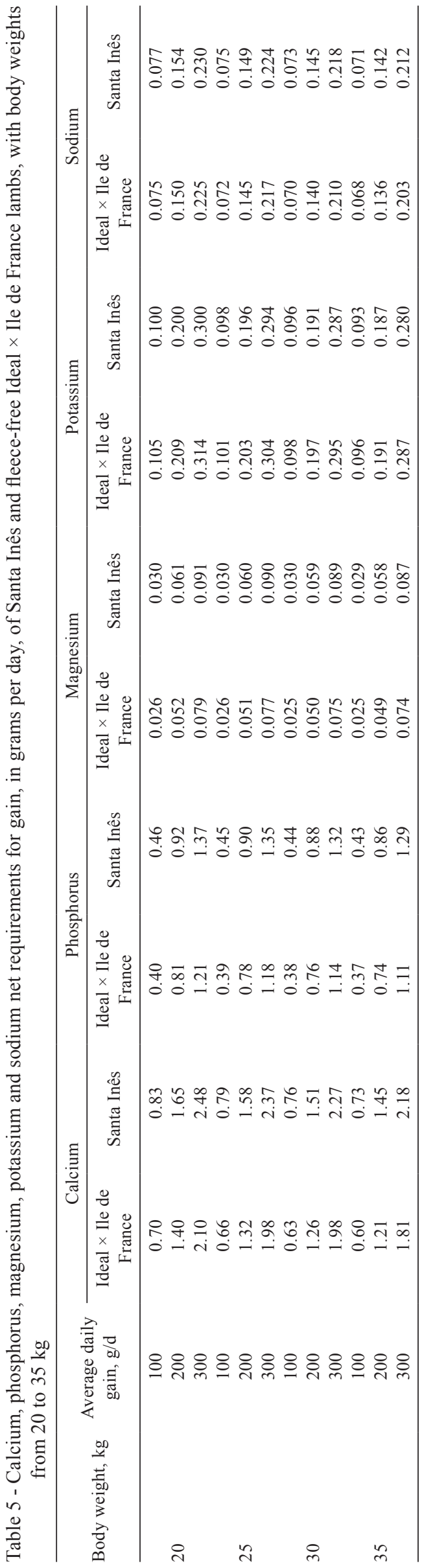

that fat acts diluting mineral concentrations in the empty body. According to Moulton (1923), these findings indicate that the bone and muscle tissues in the lambs in the present study had reached maturity, which is consistent with the fact that the protein and mineral proportions had attained constant values in the fat-free empty body.

The bodies of the wool sheep contained a lower proportion of minerals than the bodies of the hair sheep. This result indicates that the wool sheep had lower requirements for growth. Because adipose tissue has negligible amounts of minerals and because greater proportions of $\mathrm{Ca}, \mathrm{P}, \mathrm{Mg}$ and also $\mathrm{Na}$ are found in bone (Underwood \& Suttle, 1999), it follows that the lower requirement for these minerals in the fleece-free wool lambs is due to their greater fat deposition. The proportion of fat in the body increased significantly with increasing EBW. In the hair lambs, the rate of increase was $54.9 \%$, and in the wool lambs, it was $78.8 \%$. This finding is consistent with the characteristics that are expected for these animals. The wool breeds that were used in the present study were originally developed in countries that have cold climates. It is possible that a tendency to accumulate greater body reserves to allow better thermoregulation appeared during the evolution of sheep (Gregory, 1989). This tendency would be less likely to appear in Santa Inês sheep because this breed originated in regions of Brazil with warm climates (Carneiro et al., 2010).

In addition, breeds with different aptitudes (e.g., meat breeds vs. wool breeds) may differ in body composition (Oliveira et al., 1998; Oddy \& Sainz, 2002; Abdullah et al., 2010; López-Carlos et al., 2010). The wool lambs in this study were a cross between the Ideal genotype, a wellknown breed for wool production, and the Ile de France genotype, a breed used for meat production. Costa et al. (1999) reported lower levels of muscle deposition in the carcasses of Ideal lambs compared with Texel lambs, which are a meat breed. In addition, Silva et al. (2007) reported that hair sheep have higher protein requirements. Because the requirements are derived from body composition, this finding indicated that Santa Inês lambs have greater proportions of muscle and bone in their body than do wool lambs.

Physiologically, the availability and utilization of calcium and phosphorus are considered together because these minerals are closely related metabolically. A deficiency and/or excess of one of these minerals usually interferes with the efficiency of utilization of the other. The present study found that the Ca:P ratio ranged from 2.00 to 1.88 in the fleece-free wool lambs and from 2.09 to 1.95 in the hair lambs. This result is in agreement with the value that has been established for this ratio (around 2:1) for the normal metabolism of these minerals (McDowell 1992; 
Underwood \& Suttle, 1999). In the present study, the net Ca requirement for gain for the Santa Inês lambs was lower than that reported by Geraseev et al. (2001), who studied the same breed. The authors of the present study and Geraseev et al. (2001) obtained similar P requirements for the Santa Inês lambs.

The values that were observed for the $\mathrm{Mg}$ net requirements for gain for the Santa Inês lambs, from 20 and $35 \mathrm{~kg}$ of $\mathrm{BW}$, were $14 \%$ and $7 \%$ lower, respectively, than those reported by Geraseev et al. (2001). For the Ideal $\times$ Ile de France lambs, the requirements were $21 \%$ and $13 \%$ lower, respectively. Suttle (2010) reported that $70 \%$ of the magnesium in the body is present in the skeleton, whereas potassium and sodium are mostly present in fluids and soft tissues. These minerals are required for many biological functions. The $\mathrm{Mg}$ concentration in the Santa Inês and fleece-free Ideal $\times$ Ile de France lambs were higher than and similar to that reported by Rajaratne et al. (1990), respectively, namely $0.30 \mathrm{~g} \mathrm{Mg} / \mathrm{kg}$ EBW. The Mg body composition of the fleece-free Ideal $\times$ Ile de France lambs was similar to that reported by Thompson et al. (1988), Rajaratne et al. (1990) and Bellof \& Pallauf (2007), all of whom studied wool sheep breeds.

Potassium is directly involved in growth and is responsible for the incorporation of amino acids in proteins. Moreover, $\mathrm{K}$ is needed for normal insulin secretion (Suttle, 2010). Because most of the $K$ in growing lambs is found in the muscle (Underwood \& Suttle, 1999), it was expected that the Santa Inês lambs would show greater potassium requirement for gain. However, the findings presented herein showed the opposite. Using the same animals Silva et al. (2007) found higher metabolizable protein requirement in wool lambs, which may be related to the results of potassium requirements for gain in the present study. Although both genotypes showed similar potassium body composition, wool lambs presented greater requirements for gain, which could be related to their body weight. In this study a difference in the BW-to-EBW ratio was observed, in which fleece-free Ideal $\times$ Ile de France lambs presented greater EBW than hair lambs, consequently reflecting the estimate of net requirements. These results support the hypothesis of this study, that the net mineral requirements differ between breeds of a given species, so these differences must be taken into account when a diet is formulated.

The findings of the authors of the present study for the sodium composition of gain were 18 to $30 \%$ lower than the fixed value of $1.1 \mathrm{~g} \mathrm{Na} / \mathrm{kg}$ EBW recommended by the ARC (1980). These values also differed from the results of Geraseev et al. (2001) for the sodium composition in Santa Inês lambs. These differences are likely the result of differing weather conditions, since they conducted their study in a region of Brazil that has lower average temperatures than those of the site at which this study was carried out.

\section{Conclusions}

The net requirement for gain of the fleece-free Ideal $\times$ Ile de France lambs ranged from 7.77 to $6.80 \mathrm{~g} \mathrm{Ca}, 4.54$ to $4.14 \mathrm{~g} \mathrm{P}, 0.30$ to $0.27 \mathrm{~g} \mathrm{Mg}, 1.18$ to $1.07 \mathrm{~g} \mathrm{~K}$, and 0.84 to $0.76 \mathrm{~g}$ Na per $\mathrm{kg} \mathrm{BW}$ gain, and the requirements of the Santa Inês ranged from 9.57 to $8.37 \mathrm{~g} \mathrm{Ca}, 5.39$ to $4.91 \mathrm{~g} \mathrm{P}$, 0.36 to $0.33 \mathrm{~g} \mathrm{Mg}$, 1.18 to $1.07 \mathrm{~g} \mathrm{~K}$, and 0.90 to $0.81 \mathrm{~g} \mathrm{Na}$ per $\mathrm{kg}$ BW gain for the lambs from 20 to $35 \mathrm{~kg}$ BW. The net mineral requirements differed between the genotypes that were studied in the present investigation. This finding supports the hypothesis that genotype influences mineral requirements. Thus, further studies in this field of research are necessary.

\section{References}

ABDULLAH A.Y.; KRIDLI R.T.; SHAKER M.M. et al. Investigation of growth and carcass characteristics of pure and crossbred Awassi lambs. Small Ruminant Research, v.94, p.67-175, 2010.

AGRICULTURALAND FOOD RESEARCH COUNCIL - AFRC. Technical Committee on Responses to Nutrients. Report No. 6: A reappraisal of the calcium and phosphorus requirements of sheep and cattle. Nutrition Abstracts and Reviews (Series B), v.61, p.573-612, 1991.

AGRICULTURAL AND FOOD RESEARCH COUNCIL - AFRC. Technical Committee on Responses to Nutrients: Nutritive requirements of ruminant animal: protein. Nutrition Abstracts and Reviews (Series B), v.62, p.787-835, 1992.

AGRICULTURAL RESEARCH COUNCIL - ARC. The nutrient requirements of ruminant livestock: Technical review. London: Agricultural Research Council Working Party, 1980. 351p.

ASSOCIATION OF OFFICIAL ANALYTICAL CHEMISTS - AOAC. Official methods of analysis. v.1. 15.ed. Arlington, Virginia, 1990.

BELLOF G,; PALLAUF J. Deposition of major elements in the body of growing lambs of the German Merino Landsheep breed. Small Ruminant Research, v.73, p.186-193, 2007.

BERG, R.I.; BUTTERFIELD, R M. New concepts of cattle growth. Sidney: Sidney University Press, 1976. 240p.

CARNEIRO H.; LOUVANDINI H.; PAIVA S.R. et al. Morphological characterization of sheep breeds in Brazil, Uruguay and Colombia. Small Ruminant Research, v.94, p.58-65, 2010.

COMMONWEALTH SCIENTIFICAND INDUSTRIAL RESEARCH ORGANISATION-CSIROPUBLISHING. Nutrientrequirements of domesticated ruminants. Collingwood, Autralia, 2007. 270p.

COSTA, J.C.C.; OSÓRIO, J.C.S.; OSÓRIO, M.T. et al. Composição regional e tecidual em cordeiros não castrados. Revista Brasileira de Agrociência, v.5, p.50-53, 1999.

GERASEEV, L.C.; PEREZ, J.R.O.; RESENDE, K.T. et al. Composição corporal e exigências nutricionais de magnésio, potássio e sódio de cordeiros Santa Inês dos 25 aos $35 \mathrm{~kg}$ de peso vivo. Ciência e Agrotecnologia, v.25, p.386-395, 2001.

GREGORY, E.L. Thermoregulatory aspects of adipose tissue. Clinics in Dermatology, v.7, p.78-92, 1989.

KELLAWAY, R.C. The effects of plane of nutrition, genotype and sex on growth, body composition and wool production in grazing sheep. Journal of Agricultural Science, v.80, p.17-27, 1973. 
LAWRENCE, T.L.J.; FOWLER, V.R. Growth of farm animals. 2.ed. Wallingford: CAB international, 2002. 347p.

LÓPEZ-CARLOS M.A.; RAMÍREZ, R.G.; AGUILERA-SOTO, I. et. al. Size and shape analyses in hair sheep ram lambs and its relationships with growth performance. Livestock Science, v.31, p.203-211, 2010.

McDOWELL, L.R. Minerals in animal and human nutrition. San Diego: Academy Press, 1992. 524p.

MOULTON C.R. Age and chemical development in mammals. Journal of Biology Chemistry, v.57, p.79-97, 1923.

NATIONAL RESEARCH COUNCIL - NRC. Nutrient requirements of small ruminants. Washington, D.C.: National Academy Press, 2007. 362p.

NOUR, A.Y.M.; THONNEY, M.L. Carcass, softtissue and bone composition of early and late maturing steers fed two diets in two housing types and serially slaughtered over a wide weight range. Journal Agricultural Science, v.109, p.345-355, 1987.

ODDY, V.H.; SAINZ, R.D. Nutrition for sheep meat production. In: FREER, M.; DOVE, H. (Eds.) Sheep nutrition. Wallingford, UK: CABI Publishing, 2002. p.237-262.

OLIVEIRA, N.M.; OSÓRIO, J.C.S.; MONTEIRO, E.M. Produção de carne em ovinos de cinco genótipos. 4. Composição regional e tecidual. Ciência Rural, v.28, p.125-129, 1998.

RAJARATNE, A.A.J.; SCOTT, D.; THOMPSON, J.K. et al. The effect of variation in dietary calcium supply on the phosphorus requirements of growing lambs. Animal Production, v.51, p.135-142, 1990.
SAINZ, R.D. Avaliação de carcaças e cortes comerciais de carne caprina e ovina. In: SIMPÓSIO INTERNACIONAL SOBRE CAPRINOS E OVINOS DE CORTE, 1., 2000, João Pessoa. Anais... João Pessoa: SINCORTE, 2000. p.237-250.

SILVA, A.M.A.; SILVA SOBRINHO, A.G.; TINDADE, I.A.C.M. et al. Net and metabolizable protein requirements for body weight gain in hair and wool lambs. Small Ruminant Research, v.67, p.192-198, 2007.

SOBER, E. The nature of selection: Evolutionary theory in philosophical focus. Cambridge: Bradford/M1T Press, 1984. 400 p.

SUTTLE, N.F. The mineral nutrition of livestock. 4.ed. Wallingford, UK: CABI International, 2010. 579p.

THOMPSON, J.K.; GELMAN, A.L.; WEDDEL, J.R. Mineral retentions and body composition of grazing lambs. Animal Production, v.46, p.53-62, 1988.

UNDERWOOD, E.J.; SUTTLE N.F. The mineral nutrition of livestock. 3.ed. New York: CABI Publishing, 1999. 614p.

WISEMAN T.G.; MAHAN D.C.; ST-PIERRE N.R. Mineral composition of two genetic barrows and gilts from twenty to twenty-five kilograms of body weight. Journal of Animal Science, v.87, p.2306-2314, 2009.

WISEMAN T.G.; MAHAN D.C. Partition of minerals body components from a High- and low-lean genetic line of barrows and gilts from 20 to 125 kilograms of body weight. Journal of Animal Science, v.88, p.3337-3350, 2010. 